$\underline{\text { Research Article }}$

\title{
Profile of HIV/AIDS Patients Coinfected with Tuberculosis in Bumi Wonorejo Health Centre and Santo Rafael Clinic Nabire, Papua
}

\section{Profil Pasien HIV/AIDS dengan Koinfeksi Tuberkulosis di Puskesmas Bumi Wonorejo dan Klinik Santo Rafael Kabupaten Nabire, Papua}

\author{
Tri N Kridaningsih, Mirna Widiyanti, Setyo Adiningsih, Hotma ML Hutapea, Eva Fitriana, Evi I Natalia \\ Papua Health Research and Development Institute
}

\begin{abstract}
HIV-TB co-infection still becomes a health problem in Indonesia, including in Nabire district, Papua province, which has the highest number of cases. HIV and TB infections are closely related and affect the epidemiology of one another. This study aims to determine the profile description of HIV-TB co-infected patients in Nabire. This research is a descriptive study with a cross-sectional design on 90 people with HIV/AIDS selected consecutively. Data were analyzed univariately and presented in the form of a frequency distribution table. The results showed that of 55 HIV/AIDS co-infected TB patients, almost all (90.9\%) were Papuan ethnic, $70.9 \%$ were female and aged 30 to 49 years (50.9\%) with a mean of 31.309 .36 years. The majority of HIV-TB co-infected patients were married (63.6\%), holding secondary education (58.2\%), working (67.3\%), engaging in sexual activity after 17 years of age, only having one sexual partner, and did not use drugs or obtain blood transfusions. The clinical profile of HIV-TB patients showed that $67.3 \%$ of the patients were with baseline CD4 count $\leq 350$ cells $/ \mathrm{mm}^{3}, 64.8 \%$ had CD4 count at the time of study $>350 \mathrm{cells} / \mathrm{mm}^{3}$, and viral load values fewer than $5000 \mathrm{copies} / \mathrm{ml}$ (87.3\%). The therapy most widely received for patients with HIV-TB coinfection was the combination of ARV $3 T C+E F V+T D F$ (76.4\%). The most common clinical symptoms of HIV/AIDS patients were weight loss (56.4\%), cough (40\%), recurrent oral thrush (36.4\%), chickenpox (32.7\%), and tuberculosis lymph nodes (18.2\%).
\end{abstract}

Keywords: HIV/AIDS, HIV-TB Coinfection, Papua, Patient profile

\section{ABSTRAK}

Koinfeksi Human Immunodeficiency Virus-Tuberculosis (HIV-TB) masih menjadi masalah kesehatan di Indonesia termasuk Provinsi Papua dengan angka tertinggi di Kabupaten Nabire. Infeksi HIV dan TB berhubungan erat dan saling mempengaruhi epidemiologi satu dan lainnya. Penelitian ini bertujuan untuk mengetahui gambaran profil pasien koinfeksi HIV-TB di Nabire. Penelitian ini adalah penelitian deskriptif dengan desain potong lintang pada 90 orang penderita HIV/AIDS yang dipilih secara consecutive. Data dianalisis secara univariat dan disajikan dalam bentuk tabel distribusi frekuensi. Hasil penelitian menunjukkan bahwa dari 55 orang penderita HIV/AIDS dengan koinfeksi TB, hampir semua $(90,9 \%)$ berasal dari suku Papua, 70,9\% berjenis kelamin perempuan, dan berusia 30 hingga 49 tahun (50,9\%) dengan mean 31,309,36 tahun. Mayoritas penderita koinfeksi HIV-TB telah menikah (63,6\%), berpendidikan menengah $(58,2 \%)$, bekerja $(67,3 \%)$, melakukan aktivitas seksual setelah berumur 17 tahun, hanya memiliki 1 pasangan seksual, tidak narkoba maupun melakukan tranfusi darah. Gambaran klinis penderita HIV-TB yaitu 67,3\% penderita dengan jumlah CD4 awal $\leq 350 \mathrm{sel} / \mathrm{mm}^{3}, 64,8 \%$ memiliki jumlah CD4 saat penelitian $>350 \mathrm{sel} / \mathrm{mm}^{3}$, dan nilai viral load kurang dari 5000 copy/ml (87,3\%). Jenis terapi yang paling banyak diterima oleh penderita koinfeksi HIV-TB adalah kombinasi ARV $3 T C+E F V+T D F(76,4 \%)$. Gejala klinis yang dimiliki penderita pasien HIV/AIDS terbanyak adalah berat badan menurun $(56,4 \%)$, batuk (40\%), sariawan berulang (36,4\%), cacar air (32,7\%), dan Kelenjar Getah Bening (KGB) $(18,2 \%)$.

Kata Kunci: HIV/AIDS, koinfeksi HIV-TB, Papua, profil pasien

Correspondence: Tri Nury K. Papua Health Research and Development Institute, Jl. Ahmad Yani No. 48 Jayapura 99111 Tel. 081344427956Email:nurytri5@gmail.com

DOI: http://dx.doi.org/10.21776/ub.jkb.2021.031.04.10 


\section{INTRODUCTION}

Tuberculosis (TB) and HIV/AIDS are infectious diseases that still become a global health problem, including in Indonesia. Tuberculosis is the most significant cause of morbidity and mortality in people living with HIV/AIDS (PLWHA). These two diseases interact synergistically to accelerate immunological decline and result in death if untreated. PLWHA are more susceptible to TB infection than those who do not have HIV/AIDS $(1,2)$. Globally, in 2015 an estimated 1.14 million new HIV-TB coinfection cases and 400,000 thousand deaths were caused by HIVTB coinfection. The risk of TB increases 2 - 5 times at the beginning of HIV infection and rises more than 20 times in the advanced HIV stage (3). Although the TB incidence rate is decreasing globally, it was not fast enough to achieve the target of reducing TB cases by $20 \%$ in 2020 . The cumulative decline in TB cases from 2015 to 2019 was only 9\% (from 142 to 130 new cases per 100,000 population), including a $2.3 \%$ drop between 2018 and 2019 (4).

Geographically, the highest burden of HIV-TB infection is in Southeast Asia, where 3.5 million people living with HIV/AIDS and 5 million TB patients are in the region, representing $41 \%$ of global TB patients. Five countries in Southeast Asia with a high HIV-TB burden are India, Indonesia, Myanmar, Nepal, and Thailand. The incidence of TB in these countries tends to increase, in contrast to the decreasing global trend (5). Indonesia is listed in the High Burden Countries with 3 WHO TB indicators, namely TB, TB-HIV, and MDR-TB, which emphasizes the extent of the TB problem in Indonesia.

This condition has been exacerbated by the upward trend of the number of new HIV cases from year to year since it was first reported in 1987. The cumulative number of HIV patients from 1987 to September 2014 was 150.296 people, while the cumulative total of AIDS was 55,799 people. The acceleration of HIV transmission in Indonesia is still concentrated in key populations, such as injecting drug users, female sex workers, male sex workers, and transgender. In Papua, HIV transmission has been further transmitted to the general population through risky sexual relations (generalized epidemic) (6).

Papua is one of the provinces with the highest HIV/AIDS cases in Indonesia and continues to increase. Papua is in the fifth rank of most HIV cases after East Java, DKI Jakarta, West Java, and Central Java, and in the second rank of AIDS cases after DKI Jakarta. The prevalence of HIV cases in Papua is 5\%, much higher than that in Java and Kalimantan (7). The number of HIV/AIDS cases in Papua continues to increase from year to year. According to data released by the Indonesian Ministry of Health, the number of HIV/AIDS cases in Papua has increased from 22.423 (2013) to 38.123 (2016). Data obtained from the Papua Provincial Health Office in 2017 in the fourth quarter shows that the number of HIV/AIDS patients in all of Papua Province reached 32.263 cases, consisting of 11.828 HIV cases and 20.435 AIDS cases. Nabire district is in the first rank of the number of HIV/AIDS cases, which is 5.923 cases, consisting of 2.207 HIV cases and 3.716 AIDS cases. In 2020, HIV/AIDS cases in Papua increased to 44.664 cases, and Nabire district still ranks first in Papua province with 8.199 cases, comprising 3.185 HIV cases and 5.014 AIDS cases.

HIV and TB infections are closely related and affect the epidemiology of one another. HIV infection increases the risk of TB infection due to the decreased immune system. On the other hand, TB infection is one of the most common secondary infections in people with HIV/AIDS and is the leading cause of death in people with HIV/AIDS. TB infection can accelerate the progression of HIV infection to AIDS. People with HIV/AIDS have a 26-times higher risk of developing TB infection than the general population, even in those with high CD4 cells $(4,8)$. HIV/AIDS patients with high viral load values are at risk for TB, regardless of CD4 cell count (9). Every year the risk of TB infection in people with HIV/AIDS increases by around $5-15 \%$. This is due to the reactivation of latent TB infection and the degree of immune deficiency among HIV/AIDS patients (10).

Bumi Wonorejo Health Centre and Santo Rafael Clinic are health service facilities with HIV testing and counseling services in Nabire district. The increasing number of TB cases in society today does not rule out the possibility of an increase in HIV cases accompanied by TB cases. Therefore, research is needed to determine the degree of the incidence of HIV-TB coinfection and the profile or characteristics of those HIV-TB co-infected patients. This study aimed to determine the profile of HIV patients with TB coinfection who seek treatment at Bumi Wonorejo Health Centre and the Santo Rafael clinic, Nabire district.

\section{METHOD}

This research is a descriptive study with a cross-sectional design, carried out in February - November 2017 at Bumi Wonorejo Health Center and Santo Rafael clinic in Nabire district. The population was all cases of HIV/AIDS infection in Papua. The study sample was HIV/AIDS patients older than 15 years who were selected by consecutive sampling, registered at Bumi Wonorejo Health Center and Santo Rafael Clinic, and had reasonably complete medical record data. The number of medical records for HIV/AIDS patients who met the requirements was 90 respondents. All research subjects volunteered to participate in the study by signing the consent form after receiving the consent information.

Sources of research data used came from primary data and secondary data. Primary data sources were obtained through interviews with respondents, including data on socio-demographic characteristics, CD4 cell count, and viral load results. Secondary data sources were obtained from patient medical records, namely the respondents' clinical information, including HIV clinical-stage, TB coinfection status, initial CD4 cell count, length of therapy and type of therapy undertaken, and risk factors for HIV/AIDS infection. The grouped data were analyzed univariately to describe the profile of HIV/AIDS patients with TB coinfection. Further, the data results were presented in the form of a percentage table and frequency distribution. This study maintained the confidentiality status of HIV/AIDS sufferers as research subjects. This research received ethical clearance from the Health Research Ethics Committee, National Institute of Health Research and Development, Indonesian Ministry of Health through decree No. LB.02.01/5.2/KE.064/2016.

\section{RESULTS}

The total number of respondents with HIV/AIDS participating in this study was 90 people, 45 people from Bumi Wonorejo Health Centre, and 45 people from Santo Rafael Clinic. The demographic characteristics (Table 1) 
show that the number of HIV/AIDS sufferers with TB coinfection was 55 people (61.1\%), almost all (90.9\%) came from the Papuan ethnic, and $70.9 \%$ were female. Patients with HIV-TB coinfection were found mostly at the age of 30 to 49 years (50.9\%) with a mean of 31.309 .36 years. The majority of HIV/AIDS patients with TB coinfection were married (63.6\%), holding middle education (58.2\%), and working (67.3\%).

Table 1. Socio-Demographic characteristics of HIV/AIDS patients with or without TB coinfection in Nabire District, Papua

\begin{tabular}{|c|c|c|c|c|c|c|}
\hline \multirow[t]{2}{*}{ Characteristic } & \multicolumn{2}{|c|}{ HIV - TB } & \multicolumn{2}{|c|}{ HIV Non-TB } & \multicolumn{2}{|c|}{$\begin{array}{c}\text { Total } \\
(n=90)\end{array}$} \\
\hline & $n$ & $\%$ & $n$ & $\%$ & $\mathbf{n}$ & $\%$ \\
\hline \multicolumn{7}{|l|}{ Age, years } \\
\hline $15-29$ & 25 & 45.5 & 18 & 51.4 & 43 & 47.8 \\
\hline $30-49$ & 28 & 50.9 & 13 & 37.1 & 41 & 45.6 \\
\hline$\geq 50$ & 2 & 3.6 & 4 & 11.4 & 6 & 6.7 \\
\hline \multicolumn{7}{|l|}{ Gender } \\
\hline Male & 16 & 29.1 & 15 & 42.9 & 31 & 34.4 \\
\hline Female & 39 & 70.9 & 20 & 57.1 & 59 & 65.6 \\
\hline \multicolumn{7}{|l|}{ Ethnicity } \\
\hline Papua & 50 & 90.9 & 30 & 85.7 & 80 & 88.9 \\
\hline Non-Papua & 5 & 9.1 & 5 & 14.3 & 10 & 11.1 \\
\hline \multicolumn{7}{|l|}{ Marital status } \\
\hline Single & 19 & 34.5 & 11 & 31.4 & 30 & 33.3 \\
\hline Married & 35 & 63.6 & 23 & 65.7 & 58 & 64.4 \\
\hline Living together & 1 & 1.8 & 1 & 2.9 & 2 & 2.2 \\
\hline \multicolumn{7}{|l|}{ Education level } \\
\hline Low education & 16 & 29.1 & 9 & 25.7 & 25 & 27.8 \\
\hline Middle education & 32 & 58.2 & 16 & 45.7 & 48 & 53.3 \\
\hline Higher education & 7 & 12.7 & 10 & 28.6 & 17 & 18.9 \\
\hline \multicolumn{7}{|l|}{ Occupation } \\
\hline Not working & 18 & 32.7 & 11 & 31.4 & 29 & 32.2 \\
\hline Government employed & 11 & 20.0 & 6 & 17.1 & 17 & 18.9 \\
\hline Private employed & 3 & 5.5 & 5 & 14.3 & 8 & 8.9 \\
\hline Entrepreneur/self-employed & 5 & 9.1 & 2 & 5.7 & 7 & 7.8 \\
\hline Farmer & 17 & 30.9 & 8 & 22.9 & 25 & 27.8 \\
\hline Other & 1 & 1.8 & 3 & 8.6 & 4 & 4.4 \\
\hline
\end{tabular}

The clinical profile of HIV/AIDS patients with TB coinfection (Table 2 ) shows that the majority of HIV-TB patients $(67.3 \%)$ had a low CD4 count $\left(\leq 350\right.$ cells $\left./ \mathrm{mm}^{3}\right)$. Initial CD4 count is the CD4 count of HIV/AIDS patients before undergoing ARV treatment therapy. All respondents had undergone medication therapy with a period between 6 to more than 48 months, and the most common type of therapy for HIV-TB coinfection patients was the combination of ARV 3TC+EFV+TDF (76.4\%). When the study was conducted, most respondents (64.8\%) had a CD4 count higher than 350 cells $/ \mathrm{mm}^{3}$ with a viral load value of fewer than 5000 copies/ml (87.3\%).

Table 2. Clinical Profile of HIV / AIDS Patients with or without TB koinfection in Nabire District, Papua

\begin{tabular}{|c|c|c|c|c|c|c|}
\hline \multirow[t]{2}{*}{ Variable } & \multicolumn{2}{|c|}{ HIV - TB } & \multicolumn{2}{|c|}{ HIV Non-TB } & \multicolumn{2}{|c|}{$\begin{array}{c}\text { Total } \\
(n=90)\end{array}$} \\
\hline & $n$ & $\%$ & $\mathbf{n}$ & $\%$ & $\mathrm{n}$ & $\%$ \\
\hline \multicolumn{7}{|l|}{ Baseline CD4 count } \\
\hline$\leq 350$ cell $/ \mathrm{mm}^{3}$ & 37 & 67.3 & 22 & 64.7 & 59 & 66.3 \\
\hline$>350$ cell $/ \mathrm{mm}^{3}$ & 18 & 327 & 12 & 35.3 & 30 & 33.7 \\
\hline \multicolumn{7}{|l|}{ Current CD4 count } \\
\hline$\leq 350$ cell $/ \mathrm{mm}^{3}$ & 19 & 35.2 & 8 & 23.5 & 27 & 30.7 \\
\hline$>350 \mathrm{cell} / \mathrm{mm}^{3}$ & 35 & 64.8 & 26 & 76.5 & 61 & 69.3 \\
\hline
\end{tabular}

Table 2. Clinical Profile of HIV / AIDS Patients with or without TB koinfection in Nabire District, Papua

\begin{tabular}{|c|c|c|c|c|c|c|}
\hline \multirow[t]{2}{*}{ Variable } & \multicolumn{2}{|c|}{ HIV - TB } & \multicolumn{2}{|c|}{ HIV Non-TB } & \multicolumn{2}{|c|}{$\begin{array}{c}\text { Total } \\
(n=90)\end{array}$} \\
\hline & $n$ & $\%$ & $n$ & $\%$ & $n$ & $\%$ \\
\hline \multicolumn{7}{|l|}{ Viral load } \\
\hline$>5000 \mathrm{copy} / \mathrm{ml}$ & 7 & 12.7 & 3 & 8.6 & 10 & 11.1 \\
\hline$\leq 5000 \mathrm{copy} / \mathrm{ml}$ & 48 & 87.3 & 32 & 91.4 & 80 & 88.9 \\
\hline \multicolumn{7}{|l|}{ Therapy duration } \\
\hline $6-12$ months & 10 & 18.2 & 12 & 34.3 & 22 & 24.4 \\
\hline $13-24$ months & 18 & 32.7 & 10 & 28.6 & 28 & 31.1 \\
\hline $25-36$ months & 13 & 23.6 & 8 & 22.9 & 21 & 23.3 \\
\hline $37-48$ months & 10 & 18.2 & 3 & 8.6 & 13 & 14.4 \\
\hline$>48$ months & 4 & 7.3 & 2 & 5.7 & 6 & 6.7 \\
\hline \multicolumn{7}{|l|}{ Combination ART } \\
\hline $3 T C+Z D V+N V P$ & 8 & 14.5 & 2 & 5.9 & 10 & 11.2 \\
\hline $3 T C+Z D V+E F V$ & 5 & 9.1 & 1 & 2.9 & 6 & 6.7 \\
\hline $3 T C+E F V+T D F$ & 42 & 76.4 & 31 & 91.2 & 73 & 82.0 \\
\hline
\end{tabular}

The description of the risk factors (Table 3) shows that HIVTB co-infected sufferers engaged in sexual activity after 17 years of age $(61.8 \%)$ and only had one sexual partner (61.8\%). Most of the respondents had never used injected drugs, did not carry out blood transfusions and did not have tattoos.

Table 3. Risk Factors for Transmission of HIV/AIDS Patients with or without TB coinfection in Nabire District, Papua

\begin{tabular}{|c|c|c|c|c|c|c|}
\hline \multirow[t]{2}{*}{ Variable } & \multicolumn{2}{|c|}{ HIV - TB } & \multicolumn{2}{|c|}{ HIV Non-TB } & \multicolumn{2}{|c|}{$\begin{array}{c}\text { Total } \\
(n=90)\end{array}$} \\
\hline & $\mathbf{n}$ & $\%$ & 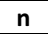 & $\%$ & $\mathbf{n}$ & $\%$ \\
\hline \multicolumn{7}{|l|}{ Sexual activity } \\
\hline$<17$ years & 19 & 34.5 & 13 & 37.1 & 32 & 35.6 \\
\hline$>17$ years & 34 & 61.8 & 20 & 57.1 & 54 & 60.0 \\
\hline never & 2 & 3.6 & 2 & 5.7 & 4 & 4.4 \\
\hline \multicolumn{7}{|c|}{ Number of sex partner } \\
\hline 1 person & 34 & 61.8 & 22 & 62.9 & 56 & 62.2 \\
\hline$>1$ person & 19 & 34.5 & 11 & 31.4 & 30 & 33.3 \\
\hline never & 2 & 3.6 & 2 & 5.7 & 4 & 4.4 \\
\hline \multicolumn{7}{|l|}{ Drug abuser } \\
\hline Yes & 2 & 3.6 & 1 & 2.9 & 3 & 3.3 \\
\hline No & 53 & 96.4 & 34 & 97.1 & 87 & 96.7 \\
\hline \multicolumn{7}{|l|}{ Blood donor } \\
\hline Yes & 6 & 10.9 & 6 & 17.1 & 12 & 13.3 \\
\hline No & 49 & 89.1 & 29 & 82.9 & 78 & 86.7 \\
\hline \multicolumn{7}{|l|}{ Tattoo } \\
\hline Yes & 3 & 5.5 & 2 & 5.7 & 5 & 5.6 \\
\hline No & 52 & 94.5 & 33 & 94.3 & 85 & 94.4 \\
\hline
\end{tabular}

The most clinical symptoms of HIV/AIDS patients were weight loss (56.4\%), cough (40\%), recurrent thrush (36.4\%), chickenpox (32.7\%), and KGB (18.2\%), as shown in Table 4.

Table 4. Description of clinical symptoms of HIV-TB coinfected patients in Nabire District, Papua

\begin{tabular}{lrr}
\hline \multicolumn{1}{c}{ Clinical Symptoms } & Total $(\mathbf{n})$ & Percentage (\%) \\
\hline Weight loss & 31 & 56.4 \\
Recurrent thrush & 20 & 36.4 \\
Feeling weak & 1 & 1.8 \\
Fever & 3 & 5.5 \\
Cough & 22 & 40.0 \\
Diarrhea & 8 & 14.5 \\
\hline
\end{tabular}


Table 4. Description of clinical symptoms of HIV-TB coinfected patients in Nabire District, Papua

\begin{tabular}{lrr}
\hline \multicolumn{1}{c}{ Clinical Symptoms } & Total (n) & Percentage (\%) \\
\hline Nausea & 1 & 1.8 \\
Dizzy & 1 & 1.8 \\
Oral candidiasis & 7 & 12.7 \\
PEP & 1 & 1.8 \\
KGB & 10 & 18.2 \\
Dermatitis & 1 & 1.8 \\
Leucorrhoea & 2 & 3.6 \\
Chickenpox & 18 & 32.7 \\
$\quad$ Chest pain & 1 & 1.8 \\
Shortness of breath & 1 & 1.8 \\
Syphilis & 2 & 3.6 \\
\hline
\end{tabular}

\section{DISCUSSION}

HIV infection can cause damage to the immune system and increase the risk of co-infection. Co-infection or secondary infection can be a major cause of morbidity and mortality in people with HIV/AIDS. The co-infection that most often accompanies HIV infection is TB infection. HIV/AIDS infection can be a factor that contributes to an increased risk of developing TB infection. The Papua Province Health office report as of June 30, 2020, stated that the highest spread of HIV/AIDS cases in Papua Province is in Nabire District (11).

\section{Socio-Demographic Characteristic}

The results of this study indicated that $61.1 \%$ of HIV/AIDS sufferers were co-infected with TB. This percentage is much higher than the rate of HIV-TB coinfection in other countries, such as Ethiopia (27.7\%) (12), Nigeria (14\%) (13), Guangxi China (33,3\%) (14), and Colombia (49,4\%) (15). In this study, it is found that women with HIV-TB coinfection were more dominant than men. This result is following the studies conducted by Aliyu et al., in Africa and Mitku et al., in Ethiopia $(12,16)$. In contrast to several previous studies conducted in Indonesia, HIV-TB coinfection is more common in men (17-20). In general, the incidence of HIV-TB coinfection is still mostly found in males because they do more outdoor activities, so the possibility of being exposed to TB coinfection is higher. A large number of HIV-TB coinfection cases among women in this study may be because women are at greater biological and social risk of being exposed to HIV-TB coinfection than their partners. The biological characteristics of the female genital tract increase susceptibility to HIV infection (21). Financial insecurity is a predominant factor influencing women's HIV risk in the United States (22). Financial gain and unemployment make vulnerable women who are without jobs turn to sex work as a means of livelihood to take care of themselves, their families, and relatives (23). Other studies in Papua reports that social behavior factors like free sex behavior, decrease its religious value and negative culture habit at prolific has risk toward disease HIV-AIDS. In addition, economic factors, lifestyle, and broken homes influence the disease of HIV/AIDS (24).

In the age variable, it is found that the age group of 30-49 years was the largest age group suffering from HIV-TB coinfection, which is $50.95 \%$ with an average age of 31.30 years. The same results are obtained from a study by Jalal et al. in 2017, where the average age of HIV-TB patients was 37.3 years (20). Mitku and Weiz reported the same results; a study by Mitku et al., reported that the mean age of HIV-TB co-infected patients in Ethiopia was 35.83 years (12), and a study by Wei et al., reported that HIV-TB coinfection occurred in the 30-45 year age group, which indicates an increased risk of HIV-TB infection in China (25). HIV and TB are linked (26), where the largest group suffering from HIV were among productive age.

This study also found that HIV-TB co-infection was primarily found in groups who were married. Married HIVTB co-infected patients had a higher percentage (63.6\%) followed by single $(34.5 \%)$ and living together (1.8\%). It is in line with research by Zhu et al., in China that showed $76 \%$ of HIV-TB co-infected patients were married, followed by widows/widowers (16\%) and single (8\%) (14). Likewise, a study by Tiewsoh et al., in India reported that the majority of TB coinfection was found in the married group (73\%), followed by single (17\%) and widows (4\%) (27). Meanwhile, a study conducted by Krisnahari et al., and Muna et al., reported that HIV-TB coinfection was found in single patients $(17,28)$. HIV-TB cases are higher in married individuals because transmission may occur through sexual contact with their partners. This indicates that heterosexual transmission was the most common in this study.

Papuans have a higher percentage of suffering from HIVTB coinfection compared to non-Papuan tribes. This study is in line with research conducted by Pontororing et al., in Papua Province that indigenous Papuans suffered more from HIV-TB coinfection than tribes who were not native Papuans (29). Research by Sylvani also mentioned that $69.4 \%$ of people with HIV-TB co-infection in Merauke were Papuans (30). Society behavior like free sex behavior, decreasing religious value and the negative cultural habit has risk towards disease HIV-AIDS. Besides, economic condition or occupation status and lifestyle also have influence towards the disease of HIV-AIDS among Papuan (24).

In this study, it is also found that the highest percentage of people with HIV-TB coinfection hold middle education level (58.2\%), then low education (29.1\%), and high education (12.7\%). Research by Karima et al., reported the opposite that people with HIV-TB coinfection was mostly found in those with basic education (69\%), followed by secondary education (55.5\%), and 39\% with tertiary education (31). The higher education level of HIV-TB coinfected sufferers can affect their behavior and understanding in receiving information about HIV-TB infection prevention.

Based on the occupational category, most of the HIV-TB co-infected patients (67.3\%) were farmers (30.9\%), government-employed (20\%), and self-employed (9.1\%). Several previous studies also reported similar results where most co-infected patients were found in the working group $(17,18,32,33)$. Zamy et al., reported different results that HIV-TB coinfection was found in those who did not work (34). Working patients generally have high mobility and social interaction, which can provide opportunities for exposure to TB infection in the workplace.

In this study, based on the respondents' statement, most HIV-TB co-infected patients said that they had sexual activity after 17 years of age, had only one sexual partner, did not use drugs, did not have tattoos, and did not carry out blood transfusions. Meanwhile, research by Agustina 
et al., stated that the risk factors for HIV-Tb coinfection were free sex (61.9\%) and needles and HIV partners (32). These imply that sexual activity was the dominant factor of HIV transmission among them.

\section{Clinical Profile of Patients with HIV-TB Coinfection}

This study showed that the baseline CD4 count in patients with HIV-TB coinfection tended to be low, mostly $67.3 \%$ with baseline CD4 $\leq 350$ cells $/ \mathrm{mm}^{3}$. These results are consistent with the study of Wondimeneh et al., where $71.3 \%$ of respondents suffered from HIV-TB coinfection with a mean CD4 of 199149 cells $/ \mathrm{mm}^{3}$ (35). Several studies have also provided similar results $(12,20)$. Nyoko et al., stated that patients who started ARV therapy with a CD4 count below 200 cells $/ \mathrm{mm}^{3}$ were closely associated with HIV-TB coinfection than patients who started therapy at a CD4 cell count above 200 cells $/ \mathrm{mm}^{3}{ }^{(18)}$. HIV/AIDS patients with low CD4 cell counts will facilitate the occurrence of opportunistic infections, including TB infection. This is due to a decrease in the patient's immune system due to HIV infection.

The CD4 count and viral load values measured at the time of the study showed that most HIV-TB co-infected patients had CD4 values above 350 cells $/ \mathrm{mm}^{3}$ and viral load values fewer than 5000 copies $/ \mathrm{ml}$. The highest percentage of the therapy length was 13-24 months, and the most type of therapy was $3 T C+E F V+T D F$. The trend of increasing CD4 counts after undergoing ARV therapy can be caused by several factors, such as adherence level, nutritional status, and drug toxicity incidence (36). ARV therapy in patients with HIV-TB coinfection does not consider CD4 cell counts; however, TB treatment remains a top priority for sufferers and must be given before patients receive ARV therapy (37). Thus, the morbidity and mortality rates in patients with HIV-TB coinfection can be reduced.

In the clinical symptom variable, the highest percentage of clinical symptoms was weight loss $(56.4 \%)$, followed by cough (40\%), and recurrent thrush (36.4\%). Similar results

\section{REFERENCES}

1. Pawlowski A, Jansson M, Skold M, Rottenberg ME, and Kallenius G. Tuberculosis and HIV Co-Infection. PLoS Pathogens. 2012; 8(2): 1-7.

2. Bruchfeld J, Correia-Neves M, and Kallenius G. Tuberculosis and HIV Coinfection. Cold Spring Harbor Perspectives in Medicine 2015; 5(7): 1-15.

3. Bell LCK and Noursadeghi M. Pathogenesis of HIV-1 and Mycobacterium Tuberculosis Co-Infection. Nature Reviews Microbiology. 2017; 16: 80-90.

4. World Health Organization. Global Tuberculosis Report 2020. Geneva; WHO: 2020.

5. Aung MN, Moolphate S, Paudel D, et al. Regional Review Global Evidence Directing Regional Preventive Strategies in Southeast Asia for fighting $T B / H I V$. The Journal Infection Developing Countries. 2013; 7(3): 191-202.

6. Lolong DB, Simarmata OS, Novianti, Senewe FP. Situasi Human Immunofeficiency Virus-Tuberkulosis di Kabupaten Merauke 2018: Ancaman pada Umur Produktif. Jurnal Kesehatan Reproduksi. 2019; 10(1): 1-9. were also reported by Rosamarlina et al., where almost all HIV-TB co-infected patients at Sulianti Saroso Hospital felt clinical symptoms in the form of weight loss, coughing, fever, and fatigue (20). Likewise, a study by Amin et al,. stated that chronic cough was the most common clinical symptom (67.5\%), followed by fever (57.5\%), weight loss (50.4\%), and oral thrush (44.1\%) (19). Weight loss in people with HIV-TB coinfection is thought to be chronic diarrhea or HIV wasting syndrome. HIV wasting syndrome is a condition in which PLWHA loses $10 \%$ of body weight and is accompanied by chronic diarrhea and fever. Research by Keithley and Swanson stated that HIV-wasting syndrome is still a common problem in people with HIV/AIDS, especially among injecting drug users and poor people, and has a high viral load value (39). Research by Wermelink et al. also stated that weight loss during anti-TB drug therapy is a significant risk factor for drug hepatotoxicity (39).

The results of this study concluded that patients with HIVTB coinfection at Bumi Wonorejo Health Centre and Santo Rafael Clinic Nabire mostly had a poor clinical profile. The increasing number of HIV/AIDS cases in the Nabire district could provide an opportunity for an increased risk of TB coinfection in the region. A more precise understanding of the need for care and management strategies for people with HIV-TB coinfection is needed so that the quality of life for sufferers can be improved and morbidity and mortality rates can be minimized. Information regarding the profile description of HIV-TB co-infected patients can be used as a reference in assessing patient care needs and clinical intervention strategies and management policies for HIVTB coinfection. Based on the results of this study, it is suggested that there is a need for the participation of the community and institutions related to high-risk behavior change interventions in Papua.

\section{ACKNOWLEDGEMENT}

The author would like to thank Papua Research and Development Center for funding the research, Bumi Wonorejo Health Centre, and Santo Rafael Clinic in Nabire

7. Riono $\mathrm{P}$ and Challacombe SJ. HIV in Indonesia and in Neighbouring Countries and Its Social Impact. Oral Diseases. 2020; 26(1): 28-33.

8. Tornheim JA and Dooley KE. Challenges of TB and HIV Co-Treatment: Updates and Insights. Current Opinion in HIV and AIDS. 2018; 13(6): 486-491.

9. Fenner L, Atkinson A, Boulle A, et al. HIV Viral Load as an Independent Risk Factor for Tuberculosis in South Africa: Collaborative Analysis of Cohort Studies. Journal of the International AIDS Society. 2017; 20(1): 1-7.

10. Albalak R, O'brien RJ, Kammerer $\mathrm{S}$, et al. Trends in Tuberculosis/Human Immunodeficiency Virus Comorbidity, United States, 1993-2004. Archives of Internal Medicine. 2007; 167(22): 2443-2452.

11. Dinas Kesehatan Provinsi Papua. Laporan Kasus HIV/AIDS Provinsi Papua; Triwulan II 2020. Papua; Dinas Kesehatan Provinsi Papua: 2020.

12. Mitku AA, Dessie ZG, Muluneh EK, and Workie DL. Prevalence and Associated Factors of TB/HIV CoInfection among HIV Infected Patients in Amhara Region, Ethiopia. African Health Sciences. 2016; 16(2): 588-595. 
13. Okonko IO, Anyanwu A, Osadebe AU, and Odu NN. HIV and Tuberculosis Co-Infection in a Highly HIVInfected Population of Rivers State, Nigeria. Journal Immunoassay \& Immunochemistry. 2018; 39(6): 636-646.

14. Zhu Y, Wu J, Feng X, et al. Patient Characteristics and Perceived Health Status of Individuals with HIV and Tuberculosis Coinfection in Guangxi, China. Medicine (Baltimore). 2017; 96(14): 1-7.

15. Ruiz L, Maya MA, Rueda ZV, López L, and Vélez LA. Current Characteristics of Tuberculosis and Human Immunodeficiency Virus Co-Infection in a Cohort of Hospitalized Patients in Medellín, Colombia. Biomedica. 2018; 38: 59-67.

16. Aliyu G, El-kamary SS, Abimiku A, Blattner W, and Charurat M. Demography and the Dual Epidemics of Tuberculosis and HIV: Analysis of Cross-Sectional Data from Sub-Saharan Africa. PLoS One. 2018; 13(9): 1-11.

17. Krisnahari KL and Sawitri AAS. Karakteristik Pasien HIV/AIDS dengan Koinfeksi Tuberkulosis di Rumah Sakit Umum Daerah (RSUD) Badung dan Klinik Bali Medika Kuta. E-Jurnal Medika. 2018; 7(11): 1-8.

18. Nyoko YO, Gede IW, and Eka A. Correlation between Demographics, Clinical and Risk Factors for HIV Infection with HIV/TB Co-infection in Amertha Clinic Kerti Praja Foundation Denpasar. Public Health and Preventive Medicine Archive. 2014; 2(2): 124-132.

19. Amin Z, Uyainah A, Yunihastuti E, and Djoerban Z. Profil Pasien Tb-HIV dan Non TB-HIV di RSCM. Buletin Penelitian Kesehatan. 2013; 41(4): 195-199.

20. Rosamarlina, Murtiani F, Setianingsih TY, and Permatasari D. Profil Pasien Suspek Koinfeksi TB pada HIV di Rumah Sakit Penyakit Infeksi (RSPI) Prof. Dr. Sulianti Saroso Tahun 2015. The Indonesian Journal Infectious Disease. 2016; 30(1): 14-21.

21. Abbai NS, Wand $\mathrm{H}$, and Ramjee G. Biological Factors that Place Women at Risk For HIV: Evidence from a Large-Scale Clinical Trial in Durban. BMC Womens Health. 2016; 16(19): 1-7.

22. Frew PM, Parker K, Vo L, et al. Socioecological Factors Influencing Women 'S HIV Risk In The United States: Qualitative Findings From The Women'S HIV Seroincidence Study (HPTN 064). BMC Public Health. 2016; 16(16): 1-18.

23. Okafor UO, Crutzen R, Ifeanyi O, Adebajo S, and Borne HV HIV Prevalence and High-Risk Behaviour of Young Brothel and Non-Brothel Based Female Sex Workers in Nigeria. BMC Research Notes. 2017; 10 : 1-6.

24. Zeth AHM, Asdie AH, Mukti AG, and Mansoden J. Perilaku dan Risiko Penyakit HIV-AIDS di Masyarakat Papua Studi Pengembangan Model Lokal kebijakan HIV-AIDS. Jurnal Manajemen Pelayanan Kesehatan. 2010; 13(4): 206-219.

25. Wei W, Wei-sheng Z, Ahan A, Ci Y, Wei-wen Z, and Ming-qin C. The Characteristics of TB Epidemic and TB/HIV Co-Infection Epidemic: A 2007-2013 Retrospective Study in Urumqi, Xinjiang Province, China. PLoS One. 2016; 11(10): 1-12.
26. Anochie $\mathrm{PI}$, Ajogwu A, Kalu GO, Akpan MIO, Onyeneke EC, Onyeozirila AC. How to control the Tuberculosis and HIV/AIDS dual epidemic. Archives of Community Medicine and Public Health. 2018; 4(2): 26-37.

27. Tiewsoh JBA, Antony B, and Boloor R. HIV-TB CoInfection with Clinical Presentation, Diagnosis, Treatment, Outcome and Its Relation to CD4 Count, a Cross-Sectional Study in a Tertiary Care Hospital in Coastal Karnataka. Journal of Family Medicine and Primary Care. 2020; 9(2): 1160-1165.

28. Muna N and Cahyati WH. Determinan Kejadian Tuberkulosis pada Orang dengan HIV/AIDS. Higeia Journal of Public Health Research and Development. 2019; 3(2): 168-178.

29. Pontororing GJ, Kenangalem E, Lolong DB, et al. The Burden and Treatment of HIV in Tuberculosis Patients in Papua Province, Indonesia: A Prospective Observational Study. BioMed Central Infectious Disease. 2010; 10(1): 1-9.

30. Sylvani MA, Handajani YS, and Gani L. Faktor Risiko Komorbid HIV dan Tuberkulosis di Rumah Sakit Umum Daerah Merauke. Journal of the Indonesian Medical Association. 2019; 69(6): 211-217.

31. Karima UQ, Sudaryo M, and Kiptiyah NM. Prediktor Kejadian TB pada ODHA di Salah Satu RS Pemerintah Bogor, Tahun 2014-2016. Jurnal Epidemiologi Kesehatan Indonesia. 2017; 1(2): 25-34.

32. Agustina $P$, Rahmawati $H$, Rusli A, Sundari T, and Wiweka IBS. Profil Pasien Suspek Resistensi Ganda Tuberkulosis HIV/AIDS di Rumah Sakit Penyakit Infeksi (RSPI) Prof. Dr. Sulianti Saroso. The Indonesia Journal of Infectious Disease. 2012;3(1): 1-7.

33. Soraya DAH and Artika DM. Profil Pasien KOinfeksi TB-HIV di Rumah Sakit Uum Pusat Sanglah Bali Tahun 2013. E-Jurnal Medika Udayana. 2016; 5(7): 5-9.

34. Zamy DA, Lestari BW, and Hartantri Y. Gambaran Hasil Terapi TB Paru pada Pasien TB-HIV di RSUP dr. Hasan Sadikin Bandung Tahun 2012-2014. eJurnal Kedokteran Indonesia. 2015; 3(3): 204-209.

35. Wondimeneh Y, Muluye D, and Belyhun Y. Prevalence of Pulmonary Tuberculosis and Immunological Profile of HIV Co-infected Patients in Northwest Ethiopia. BMC Research Notes. 2012;5(1): 1-7.

36. Yogi PD, Dian S D, Gayatri AY, Utama MS, Somia A, and Parwati MT. Karakteristik Pasien HIV/AIDS dengan Koinfeksi Tuberkulosis pada Poliklinik VCT RSUP Sanglah. MEDICINA. 2019; 50(2): 386-390.

37. Torpey K, Agyei-nkansah A, Ogyiri L, et al. Management of TB/HIV Co-Infection: The State of the Evidence. Ghana Medical Journal. 2020; 54(3): 186-196.

38. Keithley JK and Swanson B. HIV-Associated Wasting. Journal of the Association of Nurses in AIDS Care. 2013; 24(1): S103-111.

39. Warmelink I, Hacken NH, Werf TSVD, and Altena RV. Weight Loss During Tuberculosis Treatment is an Important Risk Factor for Drug-Induced Hepatotoxicity. The British Journal of Nutrition. 2011; 105(3): 400-408. 